\title{
Un-thinking the West: The spirit of doing Black Theology of Liberation in decolonial times
}

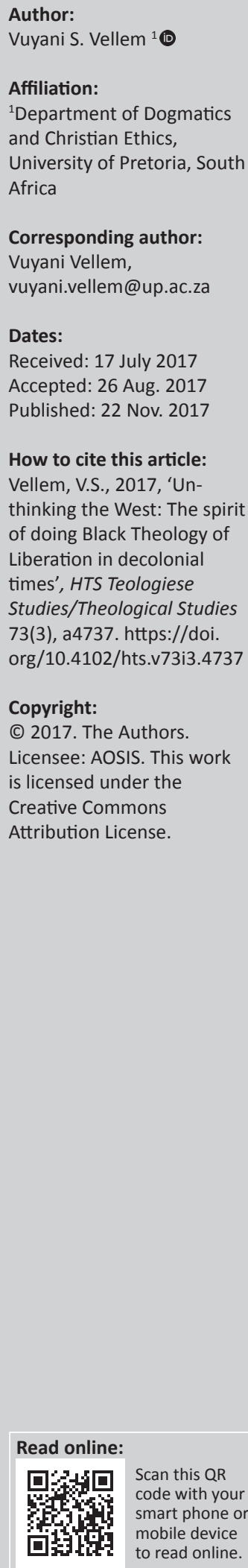

\begin{abstract}
It is indisputable that Black Theology of Liberation (BTL) intentionally un-thinks the West. BTL has its own independent conceptual and theoretical foundations and can hold without the West if it rejects the architecture of Western knowledge as a final norm for life. This, however, is a spiritual matter which the article argues. The historical arrest of the progression of liberative logic and its promises might be self-inflicted by rearticulating and reinterpreting liberation strong thought. At a time when neofascism, which is virtually an open display of psychological and ideological confusion, racism, classism, sensibilities of integralism and gender violence, having become rife, liberal democracy is arguably in crisis today. BTL has to move beyond rethinking and repeating its tried and tested ways of response to black pain caused by racism and colonialism. Un-thinking the West is not only cognitive but also spiritual. Umoya, the spirit of life, the article argues, to un-think the West, constitutes inter alia, the rejection of Hellenocentric concepts as a starting point of knowledge. Umoya should reject the self-serving periodisation of history centred on Europe, dualistic obfuscating secularism and willingness by black to occlude their knowledge systems. Without this, the article argues, the lethargic sleep, the mocking laughter of the West at the self-wounding black African remains a syndrome that arrests the translation of liberation knowledge from history.
\end{abstract}

\section{Introduction}

I am a black male and have been a student of Black Theology of Liberation (BTL) since my days at the Federal Theological Seminary (Fedsem) in the late 1980s. One of the most important things that made this school so attractive to me is its inextricable link with black consciousness (BC), a philosophy that truly inspires my reason of faith as a black person. The proverbial doublet 'faith and reason' suggests that religion or religiosity at best is a combination of ideology and faith. Since my high school days, in the 1980s, BC philosophy, as an ideology, had made an indelible imprint in my consciousness, albeit silently so. Today I could express this combination of faith and reason, that is, BTL and BC, as a profound expression of Good News, euaggelion, in my journey as a pastor, manager, ecclesiastical bureaucrat, researcher and teacher. BC as a rational and ideological philosophy for the dignification of a black interlocutor is good news for black faith. Steve Biko (2004) saw the relationship between this philosophy and spirituality many years ago. I have studied with, worked with, managed and led, and have been managed and led by all races in my journey of life. I do not like ' $\mathrm{I}$ ' in any conversation I participate in, but have used this thus far to drill some of the lessons of my school: 'disclose your location and assumptions upfront', in order to contribute with humility and responsibility.

In this article, un-thinking the West is the idea we engage and propose as a culmination of my location, especially in the Faculty of Theology at the University of Pretoria. The idea is directly related to my life-long black assumptions (BC) and faith (BTL), black religiosity so to speak. Rearticulating, reinterpreting or repeating the core ideas of BTL, whether by exponents of BTL, or outsiders and critics, takes the gains of the school backwards. It is as if by repeating its core ideas, BTL assumes the West as its 'non-believer', a quintessential contradiction, therefore, as the very foundational difference it has for years proposed as its starting point is rather blackness, the 'nonperson' not the 'non-believer'. BTL has its independent conceptual existence and in the context of de-coloniality, it might even be more dangerous to be repetitive as if BTL were a deviation from the prescribed norms of the West. So un-thinking the West might be the best option for us in the development of life-affirming forms of theological knowledge.

As Mamdani (1986:10) argued a few years ago, some concepts and trajectories of Western theology are ad nauseam; their continuous engagement perpetuates the stereotype that BTL is merely residual

Note: The collection entitled 'Spirit rising: tracing movements of justice', forms part of the 'Faith in the City' research project, hosted by the Centre for Contextual Ministry in the Faculty of Theology, University of Pretoria. Some of the articles were papers presented at the Biennial Consultation on Urban Ministry, hosted by the Institute for Urban Ministry, in collaboration with other organizations, from 17-20 August 2016. The theme of this Consultation was '\#We must rise: healers-dreamers-jesters'. 
and a deviation to the norm, namely Western cannons of knowledge and its metaphysics. That BTL has marvelled in its critique of White theology but continues to do so without demonstrating that there is a sense in which its principles and vision could be feasible might render this school as sheer theory and nothing more. Ivan Petrella (2004) is nonetheless spot on when he critiques the paradigm for this tendency, this problem of constant revision and reassertion of the core values of the liberation paradigm even though we do not agree with his solutions to this problem. What makes liberation theology to relate among others with social sciences, Petrella argues, is that Liberation theology constructs historical projects to deal with the roots of poverty (2004:27). Petrella laments the missing historical project of this paradigm in the first chapter of his book, but takes a different direction in response to the civilisation that re-cycles and keeps black people in unending pain. He argues that it might be too much to imagine that the whole of Western civilisation can be overcome (2004:79). In unthinking the West, our position is that Western civilisation can be overcome; it is crumbling as we speak. The poor and the marginalised, not Western civilisation, constitute our future for the development of life-affirming alternatives of civilisation and knowledge. These insights by Immanuel Wallerstein thus partly encapsulate the argument intended in this conversation:

When important new evidence undermines old theories and predictions do not hold, we are pressed to rethink our premises. In that sense, much of nineteenth-century social science, in the form of specific hypothesis, is constantly being rethought. But, in addition to rethinking, which is 'normal', I think we need to 'unthink' nineteenth-century social science, because many of its presumptions - which, in my view, are misleading and constrictive - still have far too strong a hold on our mentalities. These presumptions, once considered liberating of the spirit, serve today as the central intellectual barrier to useful analysis of the social world. (Ndlovu-Gatsheni 2013:31 of 76)

Ndlovu-Gatsheni, like others in the 'coloniality school ${ }^{1}$ engages Wallerstein in his discussion where he grapples with 'coloniality of power' and its relationship with development. Coloniality of power or, more strictly, coloniality is woundedness; it is wretchedness, emptiness, squalor created by Eurocentric colonialism and apartheid in our case in South Africa. Enrique Dussel, who sees coloniality of power as a syndrome, explains it 'as the colonizing power that denied what was Amerindian and imposes what was European, based on a subtle but all-pervasive racism' (2002:229). Dussel's own concept of exteriority is in the same vein another expression of coloniality, woundedness or wretchedness.

This syndrome with subtle but all-pervasive racism, this woundedness, still hovers over all of us, especially those living on the underside of modernity, ${ }^{2}$ years and decades after the official collapse of colonial and apartheid regimes. Ndlovu-Gatsheni borrows from Žižek, the notion of "“weak

1.The Coloniality School is associated with names such as Enrique Dussel, Nelson
Maldonado-Torres, Ramon Grosfoguel, Walter Mignolo and others mostly influenced by Frantz Fanon, Steve Biko, etc.

2.See, Vellem et al. (2016), especially the title, apart from the fact that the book itself is a kaleidoscope of reflections on marginalised experiences on the globe based on biblical and theological approaches that critique Eurocentric modernity. thought" as opposed to "strong thought"'. Accordingly, strong thought privileges "large-scale explanations" and "true ideas", which are "indestructible" and have the capacity to "always return every time they are proclaimed dead"' (Ndlovu-Gatsheni 2013:25 of 76). ${ }^{3}$

The idea of weak thought applied inversely decries the propensity of constant rethinking and repetition of large-scale ideas related to BTL, for example the re-articulation and reinterpretation of BTL's large-scale ideas in different contexts, such as in the advent of democracy in South Africa, the 'post' Civil Rights Movement discourses of liberation in the USA and in the defence against the attacks on Liberation Theology in Latin America. In doing this, as if willingly accepting to be recycled by the cunning logic of imperialism, colonialism and racism - the recycling of coloniality - which has gone unabated up to this day, BTL seems to compromise its strong thought through the weak thought of the West. The problem is not the re-articulation, rethinking or reinterpretation of the large-scale and true indestructible ideas of the liberation paradigm per se, but the obstinacy of supremacy and superiority by the West, ipso facto, the weak thought of the West, violently defended and propelled right into the 21st century. Ultimately one has to ask as whether this repetition is not becoming syndromic and thus an expression of failure to transcend coloniality of power. No doubt, neo-fascism is a sign of this weak thought by the West. The goal of BTL is not to convert the West. This might happen, but surely it cannot be pursued to the detriment of the historical project of the liberation of the oppressed. It is in making the strong thought of BTL feasible in liberating the oppressed from the syndrome of coloniality of power that the West itself could be healed.

The hermeneutical heritage of BTL is not and has not been Western-oriented, our argument continues. The irruption of the liberation paradigm, in its noble intent-an epistemological break away from Western theology - suggests that Western theology, philosophy, epistemology, metaphysics, aesthetics, ethics, culture, to mention but a few, were part of 'The construction of "pathological" regions in the periphery', intended to offer if not impose 'a recipe about how to become like the "West"' (Grosfoguel 2000:370). Instead, the vision and project of liberation are for those regions that were dismantled and constructed as 'pathological', to move away from becoming like the West, to become un-West, by restoring the sanity, dignity and subjectivity of black Africans and the global South. This is not at all an attempt to deny the inevitable intercourse and intersections of knowledge systems and experiences in human civilisations and human survival. The constant dilemma they pose themselves, i.e. these intersections, with the liberation vision and its quest for justice within an undeniable repugnant history of genocides, epistemicides and spiritualicides in the encounter between Africa and the West is worsened when the West itself remains an obstinate, unrepentant monster that exists as a parasite

3.The discussion of Wallerstein in the Coloniality School is rife as many of the exponents of this school like Enrique Dussel engage him in to demonstrate the exponents of this school like Enrique Dussel engage him in to demonstrate the
distinctions of the school and the logic of liberation from the cannons of Western knowledge. See Dussel (2002:222-224). 
that consumes BTL's strong thought. This is indicated by decades of thinking, rethinking and re-articulation of this dilemma, or paradox yielding very little feasible results for lives that matter. Even worse, this conversation takes place when the hardening husk of the regimes of the West in different places of the globe points to undeniable forms of neo-fascism. Thus, the syndrome of coloniality, brokenness and blackness in the context of neo-fascism requires no rethinking or rearticulating the large-scale ideas of liberation, but to un-think the West and to translate BTL's strong thought to feasibility, as it will be argued below.

Firstly, we look quite briefly at the global changes and what they mean for theology today. The main argument of this article is based on the interpretation of BTL as quintessentially de-colonialist, the second theme we address. One of the worrying signs, related to visceral politics in South Africa, is probably an indication of the challenge of what humanity means at the rupture of cognitive and instrumentalist discourses of the West, associated among others with Enlightenment Reason. Bodies speak, we argue, the bodies of the oppressed. A theology that harnesses its resources outside the Western polis by refusing to accord Western canons of thought any finality un-thinks the West. To un-think the West is a complete decentring of Western canons and a focus on making BTL's strong thought feasible. The disentanglement of BTL from the parasitic, life-killing antics of the West in the light of neo-fascism is urgent. The rationality of liberation reason can no longer coexist with Western fascism if the emancipatory logic of theology is to be useful for the sustenance of life. How can a civilisation that is intrinsically based on the doubt of the humanity of a black person ever help the world to restore creation which is in groans with pain and whose dignity is constantly being undermined to life? Imagine the racist, patriarchal, sexist and chauvinistic order experienced as a triple jeopardy of black African women lives, the recent epiphanies of racism 23 years after democracy in South Africa? 'Surely, we deserve to be laughed at' (Maluleke 2017:14) by perpetuating our pain as black people with our preoccupation to re-state, re-articulate and re-interpret in times of neofascism.

\section{A fascist supremacist order}

Western civilisation is no longer helpful to make any meaningful contribution to black life, especially when one interrogates growing fascism in the West, ostensibly in defence of the supremacy and superiority of one race against all others in the world. A glance at the global signs, when it is no longer only the human beings that are suffering, but also creation at the hands of a life-killing civilisation, presents a picture of 'The spirit of I don't Care' about the West, especially by those who are the beneficiaries of this civilisation bent on defending it at all costs. Brexit, the new French President Emmanuel Macron, a number of comments on the meaning of Trump's ascendancy to power in a country that has claimed democracy and the Rule of Law as part of its covenant suggest inter alia that there is a shift from neoliberal dominance to neo-fascism. Cornel West defines neo-fascism in this manner:
Well, neofascist, is like an American-style form of fascism. And what I mean by that is we've had a neoliberal rule, from Carter to Obama. That neoliberal rule left in place a national security state. It left in place massive surveillance. It left in place the ability of the president to kill an American citizen with no due process. That's Obama. That was the culmination of the neoliberal era. Now you get someone who's narcissistic, which is to say out of control psychologically, who is ideologically confused, which is to say is over his head. And who does he choose? The most rightwing, reactionary zealots, which lead to the arbitrary deployment of the law, which is what neofascism is, but to reinforce corporate interest, big bank interest, and to keep track of those of us who are cast as other -peoples of color, women, Jews, Arabs, Muslims, Mexicans and so forth and so on. So this is one of the most frightening moments in the history of this very fragile empire and fragile republic. (Independent Global News 2016)

\section{Edwards, Haugerud and Parikh (2017) say:}

Global narratives about the election and the referendum highlight rupture: in Europe, for example, there have arisen farright politicians who portray themselves as part of an antiestablishment movement, a trend that includes the 2016 election of the new US president, Donal Trump. (p. 195)

They continue: 'Anti-immigrant and racist sentiments not shared by all in these movements - are increasingly expressed in public, sometimes explicitly and sometimes through code and indirection' (Edwards et al. 2017:196). Hugh Gusterson (2017:209) links the election of Donald Trump with the upsurge of nationalist populism and includes inter alia Brexit, the populist government of Poland, Marine Le Pen of France and Victor Orban of Hungary. Restated, neofascism entails narcissism, manifest through psychological and ideological confusion, supported by right-wing zealots who deploy the law arbitrarily to reinforce the interests of the wealthy. Populism, subtle but all-pervasive racist sentiments, while putting the marginalised under surveillance, is a quintessential state of breathlessness. This rupture of populism, racist in sentiment that threatens liberal democracy and human rights, renders democracy itself laughable. Indeed, as Maluleke (2017) rightly posits, the mocking laughter at black lives is not only by Deadman's Creek's citizens, the Deadman's River laughing at us:

Villagers in the backyards of China are laughing at, and joking about Africa. The entire world is in stiches over our fantastic ability to wound ourselves. (p. 14)

\section{Maluleke (2017) continues:}

Our country South Africa has become the laughing stock of the world again. In fact, I am not sure if the laughter ever stopped. (p. 14)

All this is a tragic, deadly laughter, tragicomic a laughter that never stopped right into our democratic dispensation. The African wound in the reigning sprit of our frightening neofascist times is the laughing stock of the world again. It is a spirit of laughter at the colonial wound. In South Africa, one has to think about congregants who eat grass, are 'doomed' by Doom, drink petrol and engage in selfcombustion in search of miracles ostensibly for salvation in their conditions of hopelessness. Maluleke (2015) elsewhere 
reminds us that Nelson Mandela is human or was human! The shenanigans of university administrations against student protests are a potent example of mocking laughter as a response to woundedness. The link between the security of the state, the instruments and devices that one personally saw employed on campus at the University of Pretoria during protests, meant for surveillance, leaving many students miserable if not 'killed' out of university education suggests that University life has become a site of breathlessness in South Africa. It is narcissism though that one sees too, not only in this sector - the higher education sector as in Universities - but also in the African National Congress (ANC)-led government. The inability of the ANC leadership to deal with their own President, let alone the recent debate on the choice between 'white monopoly capitalism' and 'monopoly capitalism' in what was seemingly 'a festival of ideas' in the proceedings of their policy conference this year (2017), is a worrisome sign. ${ }^{4}$

All these quintessentially suggest psychological and ideological confusion as signs of our moment, a neofasicst order with sensibilities of integralism, which falsely inflames people's feelings of alienation and powerlessness, if we follow Douglas Holmes (2000). That the debate on white monopoly capitalism itself has been swung into our public space ostensibly by Bell Pottinger linked to state capture, the zealousness of the media, burglaries in the offices of the Chief Justice, the Hawks and the NPA all point to the frightening fragility of power in our times, laughable? In our South African context, one (see Vellem 2013) already argued a few years ago that politics has parasitically inhabited the realm of faith. Politicians have inculcated a habit of being believed more than being questioned or critiqued, thus operating within the domain of the rupture between faith and reason or faith and ideology. While the masses are drowning in the tributary Deadman's Creek, its citizens - the citizens of Deadman's River - are laughing; they do not care. Well, they are fascist defenders of their privilege and benefit from a longue durée of the brokenness of black lives.

There are many ways in which white theologians attempted to respond to the challenge posed by the liberation paradigm violence, ignorance, laughter and 'lethargic sleep' (Dussel 2007). In South Africa, the response to BTL and, ipso facto, the response to black resistance, is one of the best examples to discern the progression of the epistemological conflict, arrogance, laughter, lethargic sleep and its extent.

The obstinacy and unchanging heart of the white racist weak thought in moments of tragedy and tragicomic fragility of life as we see it now in our times are not new. Klippies Kritzinger (1988), almost three decades ago, identified three

4.This debate is still continuing; see the article by Hoveka (2017). We agree that in principle, it is simply hard to disentangle racism from monopoly capitalism or better racism itself. The Oxfam Report, Oxfam Briefing Paper 2016, says: 'The richest $1 \%$ now have more wealth than the rest of the world combined'. The Oxfam activists also make the point that eight individuals own as much as half of the rest of the planet. They are all men, American mostly, with one European and one Mexican. planet. They are all men,
Well, all of them are white. ways in which white theologians responded to BTL. In this doctoral thesis, Kritzinger argues inter alia that there is a need to develop white liberation theology in response to BTL with a view ultimately to finding ways in which a synthesis between black and white theologies could be developed, as BTL is according to him, an anti-white theology. Kritzinger (1988) puts it this way:

[This White theology] is not intended as a separate white theology which falls into the trap of apartheid all over again, but a theology which is intimately related to Black Theology, and which unfolds in constant dialogue with it. The missiological nature of this response is also revealed by the fact that it is structured around the different dimensions of the missiological notion of conversion. (p. 273)

Dialogue has become a fiasco. Sustaining constant dialogue between white and black theologies has not stopped white theology from implementing and making its own assumptions feasible and even still normative. The systematic and perpetual ignorance of the challenge posed by BTL, including perceptions on conversion that defy this challenge, is hardening and fascist in the 21st century. Kritzinger for example discerns three ways of response to black resistance: rejection, sympathy and solidarity with BTL. Expanding on these reactions, Kritzinger highlights the fact that the rejection of BTL is entrenched in the notion that BTL is an imported theology from Latin America that merely encourages what is termed 'black racism'. ${ }^{5}$ This evaluation, as Kritzinger rightly points out, neglects to acknowledge that 'white theology' is itself an imported ideology that worked to cause the oppression of black South Africans.

BTL has also been rejected on the basis that it is a socialist theology. As the starting point of BTL is the black people who are oppressed, the social analysis of the context and condition of blackness are key to this paradigm. Kritzinger clearly argues that one cannot make the attempt to develop a theology that is outside of the situation of a people and their country. In our view, the hypocrisy of this argument, namely, the argument that BTL is foreign and socialist, flies in the face of a white theologian who cannot succeed to detach any of the doyens of Western theology from their context, whether Karl Barth, Georg Wilhelm Hegel or Jürgen Habermas and their situations. Are they not Swiss or German, respectively? One cannot use theology as a tool of neutrality in the face of an evil such as racism and apartheid. In addition, one cannot advocate for a theology that is 'objective', a point that James Cone and BTL made many decades ago.

The second reaction, which Kritzinger dubs as 'sympathy' for BTL, is probably one of the most vexatious expressions of the supremacy and superiority of white responses in our view. It is the most dangerous, obviously for reasons of

5. Having taught BTL in the Faculty of Theology for more than five years, not only did have to contend with the fact that BTL evokes reverse racism. The debate between Desmond Tutu and John Mbiti is often cos reteen Desmond Tutu and John Mbiti is often completely ignored, including following debates such as those between Tinyiko Maluleke and Motlhabi Mokgethi, let alone the proceedings of the Eloff and Stey's Commissions, which clearly suggested favourable view of African Theology against BTL by the apartheid regime. BTL is simplistically equated to reverse racism and pigmentocracy while its strong thoughts are obstinately ignored. 
patronage and excessive vituperation by a white supremacist in what appears a benign façade, albeit a mocking laughter of an abusive attitude towards black pain. Sympathy, without transformation, or to use Kritzinger's own word, without the 'conversion', thus the transformation of the core beliefs and values of superiority, is ruthless. An attempt to know what is good and bad for black people, to tell the stories of black people on their behalf, is for us a methodological disaster if one evokes Spivak's question: 'Can the subaltern speak?' Devoid of empathy, sympathy for blacks neglects to listen to BTL and continuously insists on devaluing and reducing it to a coping mechanism for black people.

Kritzinger made these points more than three decades ago. In our democratic dispensation, it is plausible to argue, employing and expanding on his insights, this motif of sympathy in particular, that the democratic dispensation in South Africa is a 'sympathetic' pact in response to black pain in the light of the decolonial turn. It is sympathetic because the core values of racism still exist. The approach, which Kritzinger affirms, is that of solidarity with BTL. What is meant by this is that white theologians or people need to work, think, theologise, intellectualise with and not at or for black people.

Briefly, employing Kritzinger's thesis is not an examination of how far Kritzinger has hitherto moved himself. It is neither repetition nor re-articulation of BTL, the point we argue against in the heightening fascism of the West and powerful ones, but a deliberate illustration of choices made to respond to BTL's strong thought, discernible even in our post-1994 South Africa. The ideas of BTL, its independence, are rejected in sophisticated ways in post-1994 South Africa or co-opted (sympathised with), with very little expressions of solidarity with the strong thoughts of this paradigm. On the contrary, the fascist defence of privilege accrued from a longue durée of black brokenness is the dominant response. This argument thus intends to illustrate the historical arrest of the liberative rationality of BTL argued for more than four decades at least. The black people of South Africa are an oppressed and suffering group of people still in post-1994 South Africa coping and dealing with the scars of white oppression for centuries. White people are also being oppressed by a system that they have been made to understand, believe and accept as beneficial only to them. There is a need for the liberation of white people from this bondage of racism and superiority complex. The white community is challenged to understand that the Christian God is not only one of liberation and grace, but also one who is extremely angered in the face of injustice. For the liberation of white people to be possible, white consciousness is crucial to deal with. Understanding whiteness and the privilege attached to it in a society set up to benefit white people at the direct expense of black people is an important starting point. Once white people come to such an understanding and listen to the comprehensive argument by BTL prior to negating it, or defending their actions, a healthy conversation is sure to unfold. This has not happened in South Africa. It has not happened even in post-1994 South Africa as it now continues globally. Yong-Bock Kim (2014:xi) designates the world, the globe as a 'System of Apartheid'.
Kritzinger continues to write a section in Chapter 6 of his thesis about the guilt of white people. This is guilt that should be felt, according to Kritzinger, by every white person. Either their own sins perpetrated against black people or the complicity of white people during a time when national sin was being perpetrated against black people. When white people are brought to admission of injustices perpetrated against black human beings and evaluate themselves from the perspective of the oppressedit is impossible that they could not realise at that point that they too need liberation. Did the Truth and Reconciliation Commission (TRC) achieve this? Did the transformation processes and transformation appointments in universities achieve this, or as Kritzinger asked many years ago, did the idols that white people uphold and praise become more pronounced? John de Gruchy (2011) a few years ago said:

The point is very simple: have the majority of us whites in South Africa ever really come to terms with the fact that apartheid made us all privileged to the disadvantage of the majority of South Africans? The white response to the TRC, for example, was generally silent but often, 'well, we did not really support apartheid, and have nothing to apologize for!' (p. 2 of 4)

De Gruchy said this while reflecting on Tutu's proposal for wealth tax and reminisces about 'the reaction of angry whites using ill-informed arguments and giving us those gut-feelings, to more reasoned discussion about the issues Tutu has raised' (2011:2 of 4). Weak thought indeed. These idols, which have continued to hamper our reconciliation, include race, the land, money and the state. Some or many white people have such an ingrained passion for the land they took from black people and made 'the white man's land' out of that they are willing to die for it. The centralised goal in much of their actions during the apartheid and colonial periods was often financial. White people took to using black people as cheap labour, refusing to spend state resources on black people, oppressing black people in every way including financially, to make money. This love for money is one that was seemingly more important than humanity and sacrificed their relationships with other human beings. The abandonment of such idols and ways of thinking is a 'turning away' - a conversion according to Kritzinger. Such a conversion is paramount for 'rehumanisation', i.e. dignification of both black and white people. Unfortunately the structures that entrench these idols remain intact in South Africa post1994. The structural idols of whiteness persist in South Africa and the world today, the global system of apartheid. After all, what is racism without these idols?

Enough with our inspiration from Klippies Kritzinger, save to say that in 2016, he repeated the same thesis in his response to the plague of racist epiphanies in South Africa at the commemoration of the Sharpeville Massacre. Re-reading the thoughts regarding BTL in 1988 is no different in 2017 and that is tragic.

The essence of this tragedy is indeed a matter of faith. It is spiritual. Nothing could be crueller spiritually so, than a way of knowing that suppresses and defends guilt because white people know that they are guilty at least as beneficiaries of the systems that kept black people as underdogs. The ignorance 
of the heritage of the liberation paradigm is a strategy rather than a mere omission of its insights.

The religiosity of racism becomes clearer when we glance at René Descartes's philosophical scheme that became dominant and hegemonic in the West. He was influenced by Augustine, barring their differences especially with regard to their emphases on what they perceived human subjectivity to be. Augustine based his understanding of human subjectivity on God, while Descartes based it on humanity itself, ipso facto, championing a paradigm of solipsistic consciousness that became dominant up to this day in Western epistemology. The Jesuit roots of Descartes in this equation (Dussel 2007:250) suggest that we must concede that we are dealing with faith matters here, the spirit of the logic of supremacy and superiority with non-religious pretence. The religiosity of racism thus combines the roots of the Cartesian Ego which are religious, with Augustine and the Jesuit teaching having played a role in influencing Descartes. The ' $\mathrm{I}$ ' of the Cartesian ego is not capable to comprehend to the plight of a black person who cannot be the ' $\mathrm{I}$ '. The epistemological roots of the Cartesian ego are asleep to black pain. The lethargic sleep to the pain and violence meted out against black people in addition to the inability of the white people to fulfil the good of their own values are among the things that shocked Tiyo Soga when his small bag was stolen in Edinburgh. Western thinking related especially to the Cartesian ego undeniably places the rationality of Western theology that has espoused this canon as a faith challenge, a matter of the spirit lock stock and barrel. To think in a racist manner is not only a cognitive challenge, but a spiritual one too. One has to believe that one is superior! Let us conclude this section by clarifying a hermeneutic of suspicion at play here.

Low-intensity democracy, the strategy of allowing a few to have power without relinquishing economic power to the masses who were dispossessed, dehumanised and disenfranchised, was a strategy deployed at the very onset, the beginning of the pact and post-1994 covenant in South Africa to arrest the progression of the strong thought of BTL. It was a 'sympathetic' pact if not wholly pathological. Could this be the reason why Desmond Tutu raised the question of magnanimity in his proposal for wealth tax? Twenty-three years into democracy, questions have been raised rightly so about Nelson Mandela's and Desmond Tutu's 'Rainbow Nation'. Our question is different. Did Nelson Mandela, whatever trust he had in white people in South Africa - their capability to reconcile with black people and to deal with our repugnant history - including Tutu's TRC that pronounced forgiveness without contrition, not affirm the gift of what Ubuntu means to black African people of South Africa? A gift to cling to their moral and ethical cannons of the knowledge of human relations, harmony, forgiveness in the face of obstinate white superiority and continuous white benefit from our ugly past who are in addition poised to defending 'eternally' their guilt at whatever cost? Democracy could be war by different means to maintain and perpetuate their superiority! ${ }^{6}$ What then is the moral and ethical reason for

6.The debate on democracy as war by other means is argued in another upcoming paper: Vellem (2017). echoing the West in our knowledge heritage as black Africans, with neofascism raging today?

Boesak's (2017) Pharaohs on Both Sides of the Blood-Red Waters poses these questions and clearly argues that our hope is in isizwe rather than in the promises that made out of secret pacts that were agreed to in our transition to democracy. Boesak uses this notion of isizwe, meaning people, to argue that 'a people cognizant of their oppression and having taken the decision to struggle against their oppression and for freedom, justice and dignity will resist manipulation' (2017: xviii). He says, our hope then is in isizwe and we fully agree. He continues to argue that justice is not the work of one person, even Mandela, rather it is the work of isizwe, and thus faith in isizwe (2017:25). There is no much space to elaborate on isizwe, but for us it is about obediential politics, obedience to the participation of the people and trust in them, obedience to the people who put trust in leaders and obedience to this trust. For this matter we return to below.

\section{Black Theology of Liberation a discourse quintessentially un-West by faith}

Kalemba's description of BTL is one of the fascinating recent renditions of the paradigm. BTL is a creation of black theologians (Mwambazambi 2010:1 of 7). BTL is a new paradigm, a new grammar of doing theology; it must be emphasised. It is also about a commitment to a different politics with the view to liberating black people from white supremacy and superiority. White superiority is a creation of human degradation within the European provenance of knowledge with theological justification as in apartheid. BTL took a long time discussing its methodology (see, for example, Maluleke 1997; 2004; Spivak 1988; Tshaka 2010). During the developmental phases of BTL, the methodological wires of the school often demarcated by the introduction of Marxist tools are associated with doyens such as Takatso Mofokeng and Itumeleng Mosala. Comprehensively speaking, BTL is both epistemologically and hermeneutically un-West. It is anti-white, meaning, against whiteness, superiority and inferiority. It points beyond - not in dualistic terms - the promises of white theology. The spiritual foundation of blackness is outside the lethargic sleep by the West at the violence and destruction of the black. Mosala once argued that African Theology is the spiritual ancestor of BTL (Mosala). Maluleke's (1997:17-18) proposal of an emerging agenda of African Christianity, inter alia, puts AICs as too important to ignore. Boesak's (2009) views on the Black Church, even Tshaka's (2014), Mofokeng's major work on Christology (1983) and many others if not the school as a whole indicate that the conceptual independence of BTL is attained only when it seriously considers itself as un-West.

'Faith and reason' suggests that black faith, as the phases of the school implicitly indicated, requires a compatible form of logic and reason. BTL analysed the philosophical assumptions of the West, especially the dualistic nature of white theology 
among other things. Black African philosophy (see Wiredu 2006) and ipso facto, liberation reason, whose starting point is the preferential option of the poor, is the anchor of BTL and the source of its own theological grammar. For reasons of space, we select one example to illustrate this point, but before we do so, this aggregate presentation of the school's grammar by Gerald West (2009) is necessary:

$[A]$ ccording to Per Frostin, 'the choice of "interlocutors", the perception of God, social analysis, the choice of theological tools, and the relationship between theory and practice'. (p. 165)

\section{West continues:}

I use Frostin's analysis of liberation theologies because it draws on a wide range of related liberation theologies in dialogue with each other. The data Frostin uses is drawn substantially from the self-constituted dialogue of Third World theologians working together in forums such as EATWOT, the Ecumenical Association of Third World Theologians. (p. 165)

Following this brief sketch above, the importance of a starting point in the creation of liberative knowledge suggests a number of things. A starting point as in arche, a beginning, simply suggests the archaeology of a knowledge system and its grammar. In one language, for example, some alphabets are missing or absent in yet another. This by no means suggests the impossibility of harmonising different languages language both literally and metaphorically. However, there is only one way to harmonise different languages: persuasion! Dussel is at pains to show that conquest, colonisation and total exclusion of the other are different from knowledge systems that perceive rhetoric as a starting point of philosophy. Exteriority, Dussel's concept in his analysis of Eurocentrism, is on the same place as coloniality, wretchedness or brokenness. To include difference and to engage value systems that are different, persuasion is the only way to avoid violence in all forms. Sage philosophy in Africa is one example of a need for rhetoric, i.e. to engage Western philosophy with African philosophy, but without knowing the other ultimately how can one know? Umntu ngu mntu ngabantu abanye, to repeat what has become a well-known dictum of African ethics and philosophy: 'I am because we are'. Surely, one could say, 'I know because we know'. Persuasion is the way for harmonising difference.

No one among the black African womanists might symbolise the heritage of persuasion, 'coaxing' or a paradigm of persuasion in African theological thought better than Mercy Amba Oduyoye (1995). The image of a circle, in the Circle of African Women, is a motif of persuasion in the contestations of men and women resulting from patriarchal violence. Yet the constant choice by womanists, to prefer coaxing to dualism, abrasion, imposition and offense at least, when their identity is eroded by coloniality even three times more than that of their male counterpart should tell us something. A triple pain of women of colour and their commitment to coaxing their male counterpart to life-affirming relationships is a gift that the West has constantly rejected in its failure to inculcate a sense of harmonising difference. A circle is deeply symbolic in African architecture and thus epistemological architecture in contrast to straight lines. The West chooses violence, to eliminate rather than bring in! So does the ink ${ }^{7}$ of African philosophy get absented in Western philosophy not only out of the inhospitality, inability or even incapacity of Western philosophy to host the other, but to safeguard the purity and superiority of Western thought. The lived experiences of the colonised simply show that at the heart of the Western ways of knowing and thinking, elimination rather than persuasion is core.

The starting point and valorisation of the poor do not imply absenting that of the non-believer as many naïve critics of the school seem to suggest, but the formulation of an arch (archè) in which all are included for the sake of life. Dismissing the starting point of this grammar of doing theology suggests an inherent spirit of killing in the knowledge systems that target not even the entire archaeology of an alternative system of knowing, but its very beginning, the embryonic stage. The West ignores the strong thought of BTL, and thus it fails to engage the comprehensive assumptions of this paradigm. Grosfoguel explains:

During the last 510 of the 'Capitalist/Patriarchal Westerncentric/Christian-centric modern/Colonial World-System', we went from the 16th Century 'Christianize of I shoot', to the 19th Century, 'civilize or I shoot you', to the 20th Century 'develop of I shoot you', and to the early 21st Century 'democratize or I shoot you, (2011:28)' and whenever you start your own, I annihilate you. (Ndlovu-Gatsheni 2013:16 of 76, [author's own italics])

Gustavo Gutierrez explains the meaning of this starting point, 'the preferential option for the poor' by arguing, 'The preferential option for the poor may be interpreted as our living and working with the poor, but this interpretation is not complete' (2012:10). He explains:

The preferential option for the poor has three dimensions: to be committed to the poor in the practice of one's faith and spirituality; to read human history from the perspectives of the poor, or as Walter Benjamin suggests, to read human history against the oppressive grain, and to hear the Gospel as the announcement of the just kingdom. (p. 10)

The paradigm of BTL is love, what changes are the phrases, letters or alphabets we use to maintain its true large-scale thoughts and truths. This is a paradigm of hope. In discerning our current historical conjuncture, our letter of theology for the love of the poor with their efforts to becoming agents of change without neglecting the past is not about non-optional options, but a starting point to discern black faith and hope. The vision of BTL is cognitive and spiritual commitment to a justificatory logic of faith to break from the West and to move into another form of trust, trust in a new justificatory criterion for the promise of love and hope. Mendieta says in presenting a list of things on West (2013) that we must un-think:

7.In his work titled: The Ink of the Scholars: Reflections on Philosophy on Philosophy in Africa, Soulemane Bachir Diagne contests the idea that orality in African philosophy Africa, Soulemane Bachir Diagne contests the idea that orality in African philosophy is tantamount to the absence of written wisdom in Africa by pointing us to Timbuktu. The use of the word ink is inspired by this work. Diagne is not alone though in the cry for the neglect or exclusion of African philosophy in Western dominated discourses. The best example though is the dysfunctionality of the Society of African Philosophy for years leading to a rupture that took place in 2016, when black philosophers marched out of this platform. 
In his prologue to volume one of the Politics of Liberation (2007), Dussel enumerates seven conceptual limitations that have hobbled and blinded contemporary political philosophy: first, Hellenocentrism; second, Occidentalism; third, Eurocentrism; fourth, a self-serving periodization of world history that skews the perception of history in favor of the formation of Europe; fifth, an obfuscating secularism that distorts the role of religion in the emergence of modern society, be they Western or nonWestern; sixth, the occlusion and the negation of the theoretical, philosophical and conceptual contributions that non-Western have made to the evolution of both political institutions and their theoretical conceptualizations and understanding ;seventh, the devaluing and suppression of the pivotal role that the discovery of the New World in the emergence of the modern world, and in tandem, the devaluing of the contributions produced in the Americas, Asia and Africa to modern political thought. (p. 20, [author's own italics])

Any rational commitment to counter these limitations, and we emphasise by faith, is to un-think the West. Not only the logic as this has been repeated but the spirit that rejects Hellenocentrism as a starting point, the periodisation of history by the West, notions of secularism especially dualisms, affirmation of African philosophical and conceptual contributions and a politics obedient to the trust of the poor is important to inculcate. This is a spirit that exposes the ugly face of the so-called discovery of the New World, while the good of political thought of the African is preserved and affirmed. This for us is black faith.

The reaction to the starting point of BTL is a supreme example of irrationality and disbelief. It is an expression of the inability of those who seek to convert the other, non-believer, while they themselves cannot accept to be converted by the other. Such a conversion is not impossible as the likes of Beyers Naude have shown. The poor as a starting point means an urgent need to completely move beyond knowledge and models that are opaque, asleep and laugh mockingly at rather than affirm the lives of the victims. The preferential option for the poor is a red-light, a symbolic hazard for life. The search beyond the West is a search and commitment by faith entrusted to ways, approaches, struggles and models in the shadow of the totality of life killing associated with Eurocentric modernity. The denial of this starting point is alas, a matter of faith, pistis. Eduardo Mendieta (2013) says:

Faith, or pistis in Greek and emunah in Hebrew, refers to the credit one gives another, the confidence one places on another, and the trust that is placed upon someone or something. Faith like trust, is relational. It has a passive and an active dimension, as well as a quasi-reciprocal aspect. To have faith, is a volitional act. I have faith. I place my confidence and trust. At the same time, I am at the mercy, at the disposition, of he on whom I have placed my faith. I am vulnerable before him on whom I place my faith. (p. 25)

Failure to reciprocate in life-affirming ways while the victims have faith in the West renders their pistis irrational. For the excluded to credit, show confidence and trust categories of thought and faith that exclude them makes no sense. The victims thus choose to struggle for their lives, credit and have faith in their own spontaneous rationalities of survival as their trust is no longer in the West. BC is a rational expression of this faith, pistis in the struggles for live. The inability of the West to fulfil their own values in their encounter with blacks is the inability to be converted by others while only prone to converting others. To accept what the other says, Dussel says, is an act of faith (2007:20). Persuasion is the starting point of exchanging the teaching and values that are different into another world. This has not been the case in South Africa. Dussel (2007:17) says, "The entirety of Modernity, during five centuries, would remain in this state of "lethargy" of ethicalpolitical consciousness, as if "asleep," without "feeling" toward the pain of the peripheral world of the South'.

\section{Unthinking the West: Spirit rising}

Umoya! This is the word for spirit in isiXhosa. This is a word for wind too! This word is closer to the Hebrew one: ruach. It is the word for the breath of God into the nostrils of an unmoving body in the story of Creation. In the context of breathlessness, the rising spirit of a black person in decolonial times is the spirit to reject the finality of the West, conceptual assumptions that have hobbled and blinded contemporary thought in politics. It is the sprit, umoya of rejecting Hellenocentrism, Occidentalism and Eurocentrism as the starting point of the creation of the breath of life. The West has taught us about creation ex nihilo, i.e. creation out of nothing. In translating this notion of nothingness and creation, black people were reduced to nothingness, white people as creators! The grasp of what nothingness is what the West finally declares! In the quest for understanding creation, only what the West has created is what the black knows as creation. While blackness is nothing in the eyes of the West, creation out of nothing is equal to the West creating out of the nothingness of blacks. The very notion 'creation out of nothing' is not a syllable of African philosophy. It is misnomer to imagine nothing but an architect in creation, the architect of creation. So the West is an architect of black nothingness, a god that is creating what the black sees and beholds even to imagine the unimaginable about God's creation. Yes, in agreement with Grosfoguel, before Eurocentric modernity 'created racial/ patriarchal power and epistemic structures at a world scale entangled with processes of global capitalist accumulation' (2013:86). What is claimed to be creation out of nothing is in fact equalled to the ' $\mathrm{I}$ ' which could not be African and other races. This 'nothing' is factually equal to the genocides and epistemicides of the West on which the power structure of the ' $\mathrm{I}$ ' is built. The West is not our creator, umoya says.

Umoya is rising against a self-serving periodisation of world history that skews the perception of history in favour of Europe. Black Africans have history; they are not patients of history, pathological objects of the periodisation of the West, as it has seemed to be the case. Umoya of life is on the rise, and the dualism of an obfuscating secularism that distorts the role of religion is rejected in African religiosity. Umoya is the spirit of justice, power as in bia, the gift and power of life and bios, the platforms, the biospheres of life in the inclusion with dignity not the occlusion and the negation of the theoretical, philosophical and conceptual contributions that non-Western peoples have made to the evolution of both political 
institutions and their theoretical conceptualisations and understanding. Umoya is rising, in the spirit of forgiveness, coaxing and persuasion without forgetting the devaluing and suppression of the black people. Umoya is the creative participation of black people with dignity as architects of life with God the Architect of life.

\section{Un-concluding thoughts}

We engaged in an exposition that posits the heritage of BTL in the context of neofascism. To subject BTL to the weak thought of the West by repeating and articulating BTL's thought is akin to self-inflicting lethargic sleep, mocking laughter by black people. White response, having ruptured into populism, arbitrary deployment of the law, narcissism and sensibilities of integralism, is war and laughter by other means to the colonial wound of a black African. More importantly, we argue, BTL is bound to grasp the spiritual essence of the tragic obstinacy of the West to wake up to the pain of a black person. In this manner, for BTL to unthink the West, Umoya is to wake up from the lethargic sleep and mocking laughter of the West in its perpetual defence of superiority and incapacity to confront its weaknesses. Umoya is rising! The black, the non-person, is the starting point of BTL and its finality, not the Western non-believer.

\section{Acknowledgements Competing interests}

The author declares that he has no financial or personal relationships which may have inappropriately influenced him in writing this article.

\section{References}

Biko, S., 2014, I write what I like, Africa Picador, Johannesburg.

Boesak, A., 2009, Running with the horses. Reflections of an accidental politician, Joho Publishers, Cape Town

Boesak, A.A., 2017, Pharaohs on both sides of the blood-red rivers (Uncorrected Proof Manuscript), Cascade Books, Eugene, OR.

Boesak, A. \& Boesak, A., 2004, 'Truth crushed to earth will rise again: Christian theology in South Africa-Looking back', in E. Conradie (ed.), African Christian theologies in transformation, pp. 9-30, Ecumenical Foundation of Southern Africa, Stellenbosch.

De Gruchy, J., 2011, 'John de Gruchy Meditation of the Tutu tax proposal', viewed 02 July 2012, from http://kairossouthernafrica.wordpress.com/2011/08/25/johnde-gruchy-mediation-on-tut-ta

Diagne, S.B., 2016, The ink of the scholars: Reflections on philosophy in Africa, CODESRIA, Dakar.

Dussel, E., 2002, 'World-system and "Trans" modernity', Nepatla: Views from the South 3(2), 221-244.

Dussel, E., 2007, 'Transmodernity and interculturality: An Interpretation from the perspective of philosophy of liberation', paper read in (UAM-Iztapalapa, Mexico City), 1-26.
Edwards, J., Haugerud, A. \& Parikh, S., 2017, 'Introduction: The 2016 Brexit and Trump election', American Ethnologist: Journal of the American Ethnological Society 44, 195-200. https://doi.org/10.1111/amet.12467

Grosfoguel, R., 2000, 'Developmentalism, modernity, and dependency theory in Latin America', Nepantla: Views From the South 347-374.

Grosfoguel, R., 2013, 'The structure of knowledge in westernised universities: Epistemic racism/sexism and the four genocides/epistemicides', Human Architecture: Journal of the Sociology of Self-Knowledge 1, 73-90.

Gusterson, H., 2017, 'From Brexit to Trump: Anthroplogy and the rise of nationalist populism', American Ethnologist: Journal of the American Ethnological Society 14 209-214. https://doi.org/10.1111/amet.12469

Gutierrez, G., 2012, A Hermeneutic of Hope, Centre for Latin American Studies, paper 13 Vanderbilt University, Nashville, TN.

Holmes, D.R., 2000, Integral Europe: Fast-capitalism, multiculturalism, neofascism Princeton University Press, Princeton, NJ.

Hoveka, L., 2017, 'Netshtenzhe has set his pants on fire', The Sunday Independent, 13th August, p. 17

Kim, Y., 2014, 'Tributes and praise', in P. Dibeela, P. Lenka-Bula \& V.V. Vellem (eds.), Prophet from the South, p. xi, SunPress, Stellenbosch.

Kritzinger, J.N.J., 1988, 'Black theology: A challenge to mission', DTh thesis, Depart. of Missiology, University of South Africa.

Maluleke, T., 1997, 'Half a century of African Christian theologies', Journal of Theology for Southern Africa 99, 5-23.

Maluleke, T., 2004, 'African Christianity as African Religion: Beyond the contextualization paradigm', in E. Conradie (ed.), African Christian theologies in transformation, pp. 9-30, pp. 181-191, Ecumenical Foundation of Southern Africa, Stellenbosch.

Maluleke, T., 2015,'The search for a more human face for Nelson Mandela: An urgent task', HTS Theological Studies 71(3), Art. \#2941, 7 pages. https://doi.org/10.4102/ hts.v71i3.2941

Maluleke, T., 2017, 'Africa's Just One Big Joke to the World', The Sunday Independent, 14.

Mamdani, M., 1996, Citizen and subject: Contemporary Africa and the legacy of Late Colonialism, Princeton Studies in Culture/Power/History, Fountain, Kamapala.

Mendieta, E., 2013, 'Justice after the Law: Paul of Tarsus and the People of Come', Human Architecture: Journal of the Sociology of Self-Knowledge 1, 19-32.

Mofokeng, T., 1983, The crucified among the crossbearers: Towards a black Christology, Theologische Academie, Kampen.

Mosala, I., 1989, Biblical hermeneutics and black theology in South Africa, Wm. B.Eerdmans, Grand Rapids, MI.

Mwambazambi, K., 2010, 'A missiological glance at South African black theology', Verbum et Ecclesia 21, 2-7.

Ndlovu-Gatsheni, S., 2013, Empire, Global Coloniality and African Subjectivity, Oxford, Berghan, New York.

Oduyoye, M., 1995, Daughters of Anowa, Orbis, Maryknoll, New York.

Petrella, I., 2004, The future of liberation theology-an argument and manifesto, Ashgate Publishing Limited, Hampshire.

Spivak, G., 1988, 'Can the subaltern speak', in C. Nelson \& C. Grossberg (eds.), Marxism and the interpretation of culture, pp. 271-313, McMillan, London.

Tshaka, R., 2010, 'Do our theological methodologies help us to deal with situations of violence in black communities, especially Afrophobia?', Journal of Theology for Southern Africa 138, 124-135.

Tshaka, R., 2014, 'On being African and reformed? Towards an African reformed theology enthused by an interlocution of those on the margins of society', HTS Theological Studies Art. \#2070, 7 pages. https://doi.org/10.4102/hts.v70i1.2070

Vellem, V.S., 2013, 'A critical black analysis of the Church's role in post-Apartheid struggle for socio-economic justice', Studia Historiae Ecclesiaticae XXXIX(2), 113-130.

Vellem, V.S., 2017, 'Hermeneutical embers from the "Zone of non-being", presented in Thailand Bangkok, Conference on DARE, 31 May, Council for World Mission.

Vellem, V., Sheerattan-Bisnauth, P. \& Peacock, P., 2016, Bible and theology on the underside of modernity, SunMedia, Stellenbosch.

West, C., 2013, 'Donald Trump will unleash "Neofascism" in US', viewed 24 August 2017, from http://www.telesurtv.net/english/news/Cornel-West-Donald-TrumpWill-Unleash-Neofascism-in-US-20161201-0033.html

West, G., 2009, 'Human flourishing and social transformation: Bringing embodied theology into the public realm', Reformed World 59(3), 163-180.

Wiredu, K., 2006, 'Toward decolonizing African philosophy', in E. Antonio (ed.), Inculturation and postcolonial discourse in African theology, pp. 291-331, Peter Lang, New York. 